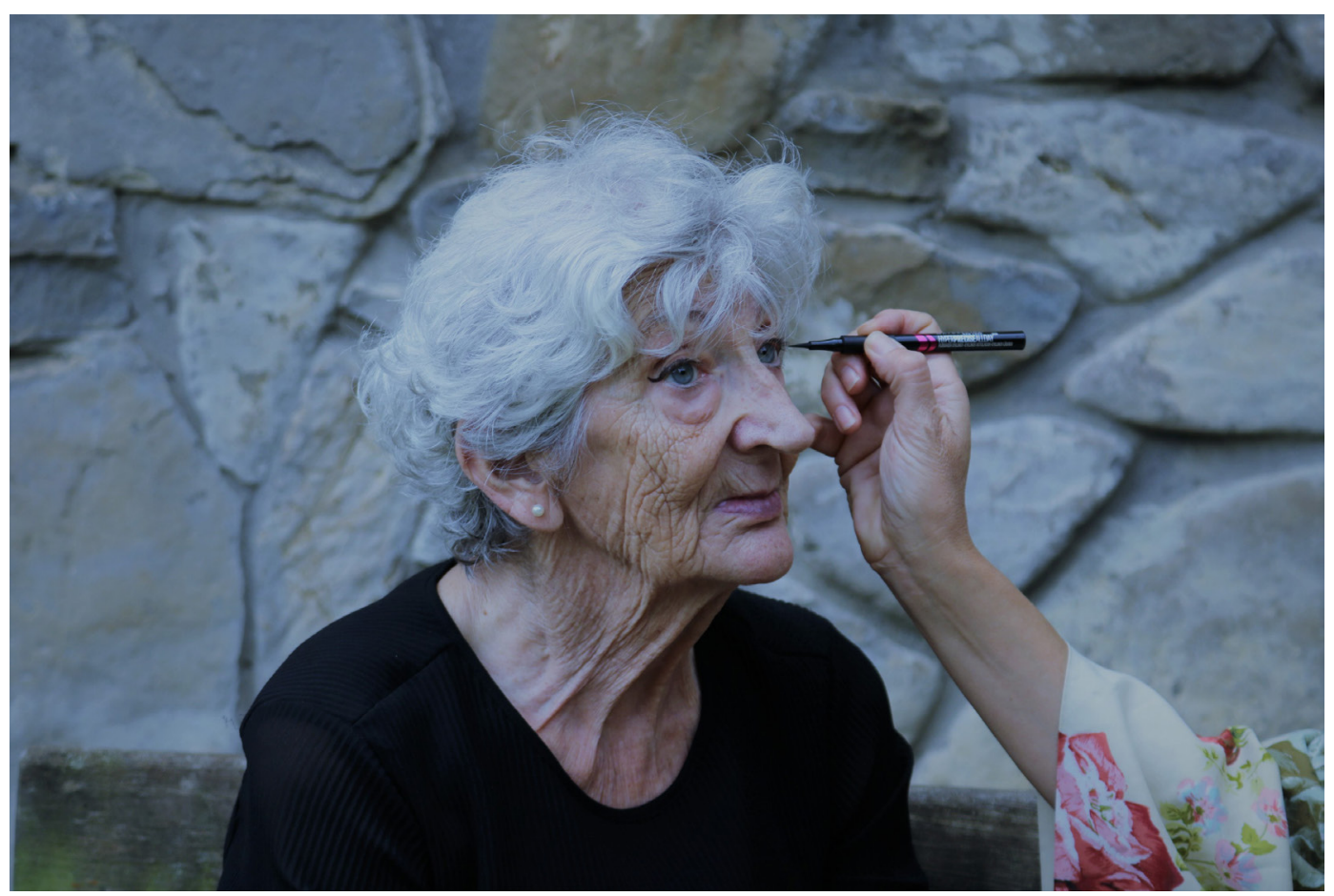

Anita Pueyo 85 años. Maquillándose para una sesión de fotos.

\title{
Ponerse en la piel de personas con demencia
}

\section{Técnica}

Fotografía digital.

\section{Reflexión}

No recuerdo una experiencia parecida a la vivida en los últimos meses. Se rompe la fantasía que la vida está bajo nuestro control. Vemos las tripas del funcionamiento profundo de nuestro sistema. Realizamos duelos personales, relacionales, económicos y sociales... todo el planeta. La fotografía tiene como objetivo concienciar sobre la importancia del cuidado de las personas vulnerables como son los niños y los ancianos.

\section{Autoras}

Ana Moreno Pueyo. Arteterapeuta. psicóloga. profesora universidad de Zaragoza.

Anita Pueyo: mi madre de 85 años siempre nos acompañó y vivió apoyándose en la creatividad y el arte en sus diferentes manifestaciones.

Izarbe Ausieto Comunicación audiovisual en la Universidad Rey Juan Carlos de Madrid.

Arteterapia: papeles de arteterapia y educación artística para la integración social.

Monográfico: Las miradas del arte y el arteterapia en tiempos de la Covid19. ISSN-e: 1988-8309 https://dx.doi.org/10.5209/arte.75877 